\title{
The Ottoman Familicide in Goffe's Bajazet the Second (1618)
}

\author{
Fahd Mohammed Taleb Al-Olaqi
}

University of Jeddah, Jeddah, Kingdom of Saudi Arabia

\begin{abstract}
The research paper studies the representation of Sultan Bajazet II in Thomas Goffe's The Raging Turk, or, Bayazeth the Second (1618). The play represents a series of plots involving intrigues and treacheries between the ambitious Bajazet II, his three sons, Bashas and generals. The theme of slaying clans in Turkish dynastic disputes is a significant motivation for the dramatists to make the Turk prevalent in shows in early modern times. Elizabethan depiction of the Ottoman sultan is as a merciless killer of his family members in revenge tragedies or history plays set in empires. The death or deposition of a sultan bringsconstantlya period of disorder and catastrophe in the Ottoman Empire. The furiousBajazet, however, satisfies Goffe's aesthetic and personal notions about the Ottoman clan killings. The Elizabethan audience prefers to see the defeated and condemned Turk plays.
\end{abstract}

Keywords - Goffe,Bajazet II, raging Turk, Ottoman, murdering sons, treason.

\section{INTRODUCTION}

Goffe's Bajazet the Second is based on the historical emperor of TurkeyBajazet II (1481-1512). The character of the Sultan is central and hardly the play can exist without him. The play performed at Christ Church in 1619 to indicate an English interest in the affairs of the Ottoman Court. The London theatre representations of the irreconcilable Ottoman protagonists are a trend of the Ottoman matter. Elizabethan and Restoration playwrights invoked the spectre of an Islamic threat by representing some great Ottoman sultans. The English were "belated players on the world stage" who necessarily approached Ottoman, Moroccan, Mughal, and other Islamic states with eyes of admiration and envy (McJannet 2006,p.184).According to Professor Nabil Matar, 'It was plays, masques, pageants, and other similar sources that developed in British culture the discourse about Muslim Otherness [such as] Bajazeth, Ithamore, and Amurath became the defining literary representation of the Turk' (Matar 1999, p.13).The Elizabethan population were moved by great sentiments of anxiety, fascination, or hope of mutuality, to be kind to ordinary foreigners. Elizabethan writings explore historical issues of the Ottoman Empire, its culture and its society. Goffe raises serious concerns on the Ottomans' political, religious and military power. Likethe English Queen, the Ottoman Sultan was a performer of a larger dramatic event in which the populace was the audience.

The popularity of the dramatic Turkish material went high in the end of the sixteenth and beginning of the seventeenth centuries. A handful of plays concentrated on Turks or the Ottoman Empire. Farhana Khan states that pseudo-histories of the Ottomans such as Goffe's Amurath and Bajazet, Kyd's Soliman, and Greene's Selimus are actedon London stage to amuse and acquaint the audiences with the governmental systems in the Orient, although they were perceived as antagonists by the Elizabethan public because of the medieval heritage (Khan 2001, p.141). Goffe's Bajazet II establishes how the early modern English utilized theatre as a place to test out ways in which to deal with the Ottoman other. The skills of performance engaged in the way Ottoman characters are addressed inpolitics, their seating positions, staging manners, costume changes, etc. Burton thinks that Turkish shows are not "direct reflections of historical circumstances" nor is there a "collinear relationship to trace between the Turkish plays and the course of AngloIslamic relations"; they do, however, present a "triangulation of anxieties, desires, and real material conditions" (Burton 2005, p.33).The infinitely repetitive and the greatly intertextual disavowal of Ottoman actualities in the Ottoman dramas define in advance the performance of the characters.

Elizabethan author's commitment publicise the Ottoman sultans. This establishment of dramatic contact of fascination and enmity signified both exoticism andbarbaric cruelty.Vitkus finds out that the Turkish monarch is portrayed as a worshipper of the devil and his faith as Satanism. This, essentially, points to the Western typecasting and representation of the Turk as anepitome of evil. "The stereotype of the devilish Moor or cruel Turk was sometimes employed to demonstrate the supposed iniquity of Islam and to portray Muslims as agents of Satan" (Vitkus 2000, p.15). English Renaissance interest and concern about the Ottoman Turks led to an outpouring of texts passing on notions and information about the Ottoman Empire (1299-1922) whose power in the sixteenth and seventeenth centuries 
prolonged even as far as the English network. In the sixteenth century, English playwrights joined most continental actors in demonstrating the Ottoman Turks on theatre through a fascination that fluctuated between terror and competition.

Goffe andhis contemporaries used the Ottoman history to exploresome topics on ideology and administration in their own days. One reason,some dramatists frequently might have been interested in the biographies of the Ottoman sultans to attract his spectators by appealing the early modern interests in the Ottoman history and English socio-political arguments. The Elizabethan Turkish plays pleased both interests at the same time. Eventually, historiography and dramaworked well tochallenge the power and the prestige of the dreaded and scorned Ottoman 'Other'in treating its image through performance, reception, politics, and artistic contexts. Matar proposes that English dramawas an antipropaganda vehicle detaching some light on the association of Eastand West, which was screenedwith stereotypes and false concepts:

The way that English dramatists, preachers, theologians and others confronted Islam and Muslims was by fabricating images about them by arranging protagonists and geography in a manner that was disembodied from history and cultural surroundings. . . As long as the sphere of the action was fabrication, the victory was won by the Christians. Outside that sphere, Englishmen and Britons treated Islam as a powerful civilization which they could neither possess nor ignore(Akalin 2001, pp.102-3).

The Ottoman heir-ship was not established in the royal household. Preferred sons did not always turn out to be an heir to the throne. On the other hand, even with some plain encounters, the Ottoman territory never was separated between heirs and no Ottoman ruler seems to have considered making a system for succession. Murad I (1362-89), Bayezid I (1389-1402), Mehmed I (1413-21), Murad II (1421-44, 1446-51), and Bayezid II (14811512), all brutally eliminated their brothers and other contenders rather than share (or lose) authority. To such extent, Mehmed II (1444-46, 1451-81) had codified the new principle as the Ottoman law of fratricide (Goffman 2007, p.38).The over-ambitious Ottoman sultans advocate the suspicious moral ethics to gain and retain kingship. Joy Pasini remarks that stories frequently recited about the Turk, Moor, or other Oriental characters in sixteenth and seventeenth century histories and dramas are about brothers killing one another, fathers killing sons, and sons killing fathers (Pasini 2001, p.31).For instance, Goffe's BajazetIIcould have also been inspired by his current Ottoman ruler Sultan Mehmed III (1566-1603), who assassinated nineteen of his brothers along with others on ascendingthe Ottoman throne. Simultaneously, the Turk plays warned about the threats of an imperial future established on the killing of kin, countrymen, and fellow Christians, which the dramatists anticipated as an crucial part of building a kingdom as well as something that England should avoid at all expenses (Pasini 2001, p.32). In the case of Prince Bayezid, for example, perhaps he was able to eliminate his competitor elder brother Jacup with virtual ease because Bayezid who was on the battlefield at Kosovo in 1389 accomplished the conquest of the campaigning armed forces when his father was assassinated. Jacup, meanwhile, had the tragedy to be far away in Anatolia (Goffman 2007, p.38). The same theme is mentioned in Goffe's Amurath. The Aga Schahin and others retell Bajazet that 'the Turkish Lawes' need Jacup's death (Amurath, V,iv,143). The fact is that Bayezid historically was a younger son and he and Jacup led armies, and they proposed a vibrant difference between the Ottoman and other European kingdoms. In this Ottoman case, there was no legitimately system for the kingship until the succession essentially occurred. In other words, all male successors were eligible for the throne and they were anticipated to be capable to assume it even though only one would do so.

The Ottoman reforms in regulations leading the transfer of power did create some complications. Historically, civil war possibly goes together with Orhan's and SultanMurad's assumptions of authority, and it indeed historically happened to SultanBayezid II and Sultan Mehmed I, with every conqueror callously having his opponents hunted down and massacred. Such ferocity may have merged power, for every imperial loss evidently accompanied in a dangerous instant for the Ottoman government;however it correspondingly gave a perception of savagery and inclined to create anger and confrontation. Subsequently Jacup's elimination, for instance, Bayezid II originated a long conflict contrary to rival states in Anatolia who expanded support even from Turkoman supporters of the House of Osman, irritated that their victor, Jacup, had lost the fight for the Ottoman power (Goffman 2007, p.39). Goffe's Bajazet IIemphases on the military atrocities of the Bajazet family in which every family member is also militant. It lures the consideration of the spectators to the native violence required by the competitors to the sovereignty to establish their capability to make kingdoms.

The episode of the Ottoman succession and the unnatural weakness of kinship ties within the Turkish royal dynasty is an attractive theme for many Elizabethan and Restoration writers. Therefore, stories of the rise and ruthlessness of Bajazet captured the imagination because they expressed a powerful paradox at the heart of the problem of Turkish power, namely the vulnerability of an uxorious sultan to being undermined by his inordinate 
ambition of power.Goffe captures the horrible acts practised by the Oriental people and the pride of Turks in his plays.Purcas, a British traveller in the days of Goffe, says: 'The mighty Ottoman is the terror of the Christian world' (Chew 1937, p. 324). It is the true image of what was to be the fundamental feature of the cosmopolitan Ottoman Empire.In the eyes of the Christian Europe, Constantinople had turned Islamic. The setting of the play is Constantinople which echoes the significance of the city and the distinct place it has in the collective conscience in Europe. Bajazet calls it 'great city of proud Constantine' (I,vi,39). It is recurrently associated with the name of the Turkish sultans to create the image of supremacy and magnificence. Goffe seeks a glory victory of the Christian hero over the Ottomans to restore the great city of Constantine. The idea of the fraudulent sultan is a disruption of Christian oneness and unity as well as a threat to Western identity. In that sense, captivity as a dramatic theme reinforces the inescapable otherness of the Ottoman sultan, who is linked with cruelty, oppression, tyranny, lasciviousness, etc.(Akalin 2001, p. 869).

The comprehensive popularity of the sultanic character over the Elizabethan commercial theatre in London was successfully accomplished byGoffe's Bajazet the Second.The rise to a tendency to exaggerate the newness of Turkey as perceived by early modern writers from the late Elizabethan period onwards, which, with the revival of English commercial dealings with the Ottomans in the 1580s, has been presented as a sort of rediscovery of Turkey. English authors in the early seventeenth century admired the Ottomans as being magnificent, great, and civil - one stating that the English traveler "could not find a better scene than Turkey" (Blount 2008, p. 58). Elizabethan curiosity and anxiety about the Ottomans made great volumes in the form of travel literature, historical and political treaties, polemical and religious tracts, ballads, poetry, fiction and drama, possibly the best way of conveying notions and data about the Turks who enthuse fear and fascination in Europe (Akalin 2001, p.15). Murad evidently considered Queen Elizabeth as his subordinate and expected her role as an obedient vassal (Faroqhi 2004, p. 7).The Grand Turk Murad whose dynamic reign was the apex of Ottoman political and economic development. The wide publicizing of plays written about the Ottomans reproduced the history of political, military, economic and cultural associations between the Ottoman Empire and Europe (Akalin 2001,p.33). England's curiosity in the Turk increasingly continued to grow. The Turks had further drove the English commercial and economic interest in the Ottoman Empire (Minchinton1969, p.7).Samuel C. Chew finds in Goffe's The Raging Turk or Bajazet the Second (1631) 'scenes of extravagant cruelty got down only to amalgamate scattered episodes from various reigns which found in Knolle's The General History of the Turks (1603) (Chew, 1937, p. 492). Although,Knolles condemned Christendom and Europe's fascination with the Ottoman Turks (Knolles 1603, "Introduction"), this enormous chronicle has really comprehensive data about the Sultans, containing passages about their physical appearance, personality, personal interests, and religious faith. It is obvious that Knolles marked this text to inform Christians with their mortal foe, the foe of their faith. It seems to attack Latin Christendom's appeasing plans of not uniting against the Ottoman Turk, in campaigns of Crusades. In fact, according to Orhan Burian:None of the plays [about the Turks], with the possible exception of Tamburlaine, counts among the great plays of the age. Yet, as evidences of the colorful picture that existed in the Elizabethan mind with regard to the East and especially to Turkey, their significance is undeniable, and does compensate considerably for what they lack as creative works (Burian 1952, p. 220).

The themes of Ottoman dethronement, death or accession of sultans are frequently overlooked by Eurocentric literature (Kugler 2012, p.22).In this play, Goffe has developed his fascination in the historical tyrant character of Bajazet the Second. Many scholars consider this play; Goffe seems to be fascinated with the alleged evil of the Turks and their insatiable greed (Bowers 1987, p.157). Though Elizabethan dramatists stated their admiration of Bajazet's personality for over two centuries, he was essentially a creation of the European fancy. It is this portrayal that has led Greville to provide information of the character of Soliman as a fascinating figure in the chronological European accounts of the Turks. In contrast, many playwrights have subjugated the customs of the Sultan to be an icon of Oriental violence. The terror from the Ottoman Empire has made Goffe to establish Bajazet's real history in Europe by conspiracies of disreputation and inhumanity. Goffe personifies the military might and confidence of the Turks, but not the negative personal qualities attributed to the sultans in some of the sources and in later academic plays such as The Raging Turke (1618) and The Courageous Turk, Amurath (1619). These plays of Goffe, inscribed in the reign of James I, are remarkable essentially on story of the sensational atmosphere, and the incidents involving bloodshed, cruelty and murder. The Raging Turk is a tragedy of Emperor Bajazet II, who is dreadfully trying to grasp onto his command. On the other hand, plotting sons, and an assuming brother prevent him from doing so. While trying to avert his heir, confusion consumes the public, and claims at least sixteen lives. The end of the play resolves with Bajazet being poisoned, and his 
grandson Solyman is crowned emperor. The play is wellknownfor "The modell of a doleful historie" (I,ii, 114) of Bajazet II. The insanity and rage of the Emperor and his sons' fight for the kingship, end in the persisting Prince Selimus' victory over others. The emphasis of this play's plot is on a different aspect of Selimus' antiquity. The tragedy,The Raging Turk, merges scattered episodes of unbelievable cruelties from numerous Ottoman sovereignties. Therefore, Goffe's masterpiece was assessed for designing "the lowest level which literature in this genre ever reached" (Rice 1926, p.349). Rice argues that the drama displays an amazing collection, diversity, and ferocity of action that proposes a theatricalfancy irritated practically to the fact of irrationality. Nevertheless, it looks to this dramatist that what is significant in this chronicle of numerous killings, toxining and suicides, is that it enterprises family the message that bloodshed is legitimized when it concludes, rather arbitrarily, in the appearance of the best contender for the crown (Rice 1926, p.349).Linda McJannet remarks that hostile western accounts of Turkish history and culture contained elements of admiration and self-critique (McJannet 2006, p.178). Whereas the Bajazet and his sons'approaches implemented by the Ottomans in the drama are evidently violent,the Elizabethan audience of these plays could not have surprised the public since some cruelties of the Tudor governments happened in the recent past.

\section{THE TYRANNY OF BAJAZET}

Elizabethan playwrights have enthralled by the Turks' capability to endure even the most tyrannical of administrations. The Turkish Sultan Bajazet II was an anathema to Englishmen, as his name became a byword for tyranny. Goffe's Bajazet II exploits the wide-ranging taste of the Jacobean community for massacre and chaos on platform. The play mainly divulges through ideas and fictions circling around perceptions of tyranny and Ottoman repression.John Foxe's History and Tyranny of the Turks, is a clear dubbed source of writing hostile accounts about the Ottomans. Tahar Bayouli remarks that the Orientalist tradition of Elizabethan drama was closely linked to the revenge play or the tragedy of blood starting with Marlowe's Tamburlaine which displays a first example of the Turkish bloody scenes which strongly mark all Elizabethan drama (Bayouli 2008, p.115).Thus in The Raging Turke, the cruelty of the Turkish ruler is surpassed only by the bloody appetite of the ego of the ruthless sultan:

Mesith.But he is cruell, bloody, and his pride

Vnsufferable great- Proud Baiazet,.../

Thou art defam'd/ With Tyranny and wrong (III, I,82-86).
Like other Senecan tyrants, Bajazet strives for absolute power. His ambition is not confined to the throne as he envisages expansion. The complications and ideological implications of demonstrating the overthrow andthe humiliation of the Grand Turkon the European stage are apparently unique. The ancientintertextuality of the Ottoman Empirehas inaccuratelycreated wide-ranging accounts revolving around the historical Sultan Bayezid II by picturing, fabrications, booms and changes of different texts.Goffe's play establishes a violent subjective tyrant Turk, which is perceived as "alien, strange or hostile". Thus, this"threatening other-heretic, savage. . . AntiChrist--must be discovered or reinvented in order to be attacked and destroyed" (Greenblatt 1980, p. 9). The tyrannical Ottoman Empire with its enslaved pages, isolated and cruel eunuchs, was prepared to contrast with the benevolent ideals of the absolute kingdoms in Europe. Throughout the Elizabethan age there was a predominant cultural attitude that demonised the Turks (Belgasem 2013, p.105). Esin Akalin says that the depiction of the Ottoman Empire through Western Christian thought explores the fundamentals of the negative images of the Ottomans and perceptions which have led to conversational disputations and tensions within both its historical and the dramatic contexts (Akalin 2001, p.75). The prototype of the ideal sovereignstands for tyranny andoppression. He paints his image withaggravated features representing a model kingand a cruel tyrant respectively, and he stood for historical or contemporary personalities. Goffe's imagination contextualized his intertextual character by recognizing his tyranny. Bajazet's play represents the Englishanxiety about the power of Ottoman Islamic imperialism. The elaborate Ottoman spectacles sought to incorporate realistic portrayals of battles with advanced engines bombardmentprojectiles and armed men attacking their opponents. The ultimate defeat of these opponents bore witnessto Ottoman superiority in arms, a superiority well knownin Elizabethan England(Akalin 2001, p.96). Posini remarks that the plays that portray Islam transfer this type of murdering to cruel, tyrannical rulers rather than just rulers, so the classical paradigm has shifted within them (Posini2011, p.183). The story of killing Prince Mustafa by his father Sultan Suleiman and Mehmet III (Mahomet III), in 1603 killing nineteen of his brothers to avoid competition for the throne, 'shocked' Europe as well as the Islamic World. Playwrights such as in Fulke Greville's Mustapha (1608) Greene's Selimus (1603) and Goffe's Amurath and Bajazet made use of material dealing with Ottoman Sultans and issues. As in Goffe's Amurath, Amurath embarks on his military campaign; he appears to awaken his antagonism by considering it as an obligation: 'Our furie's patient! Now will I be a Turke' (III,ii,9). 
Slotkin remarks that "the importance of socially constructed identities in determining behavior and maintaining the imperial polity" (Slotkin 2009,p. 231). As said by Linda McJannet, judgmental nicknames associated with the Ottomans in the sixteenth and seventeenth centuries involved - bloody, -cruel, and -barbarous. The Turks were compared to forces of nature (whirlwinds or floods) or beasts (wolves, vipers, boars) and portrayed in inhuman terms such as - unbridledor — swarming. Their rule was called as - tyranny or a -yoke. Indeed these derogatory epithets are only a portion of the representations that early modern discourse used to refer to the Ottoman Turks:

The term "Tyran[t]" suggests a critical view of such methods, but other passages suggest that Cambini could not help admiring the Ottomans' military and political success. He describes Murad II as "a man of truly great power and also of great understanding in wars, who ... brought underfoot those noblemen of his nation that held any parcel of his dominion, and . . . reduced to his obedience all the Lesser Asia" (McJannet 2006, p.42).

As the overpoweringly destructive view of the Ottoman Other overcame in the late Elizabethan period, the opposition between English civility and Oriental barbarism facilitated to outline the civilization of England, which was in search of a collective foundation in religion and politics (Beck 1987, p.67). The entirepower and brutality of the Turkish Sultan endorsed him to subjugate his opponents and launchcomprehensive control over the overwhelmed nations as well as any foes(Khan 2001, p. 155). In a departure from the Medieval tradition of the Oriental stereotype, Goffe has challenged the anticipations of the Elizabethan audience by employing the Ottoman Sultan in the protagonist of the classical hero. The play demonstrates that at least the Ottoman officials accept kin-killing to administer Ottoman justice. However, the play demonstrates that it too is lacking the appropriate attitude toward mercy and forgiveness among the leadership members of the Empire. It proposes a fundamental political divergence between the Ottomans and the Europeans.

Christian allied invited the Ottomans to intervene in their civil wars. The Ottomans first founded a bond of vassalage and demanded armed contingents as well as a tribute before increasingly joining these domains and their governing elites into the Empire (Faroqhi 2004, pp.7580). Those obligations to the Ottoman Empire provided resources, raw materials, agricultural products and soldiers, paid tributes, gathered information, and functioned as a buffer between the Ottomans and their Christian rivals. To build up the control over their vassals, the Ottomans devoted a janissary brigade to their support, conserved the final word in their election, played local factions off against each other and fortified strategic positions, the garrisons of which were paid by the citizens. To a certain extent, the system operated, even though the Ottomans had to tolerate their vassals' change of directionthroughout critical periods such as the Long War of 1593-1606 (Inalcik 1994, p.89). Farhana Khan notes that the Ottoman 'despotism and cruelty became integral indeed necessary, to the demonized picture of Oriental invincibility. If for no other reason, the relentless rise to glory of the Turks required some explanation for the fascinated English public whose attention had recently been turned towards the remarkable Princes, Bassas and Soldans of the East' (Khan 2001, p. 155). Like witchcraft, Bajazet has killed his brother Jucub which is a portrayal of himself as a fratricide and a tyrant during the early years of his reign. In Bajazet Goffe was arresting an appropriate sentence not on a proud king who was obsessed with nobility and power, but on a wicked and ungodly criminal, who had destroyed his own elder brother in a most cruel manner.

Baia.My desires are crown'd,

And from the gate of Limbo, where I sate,

I feele my spirits knocke against the heavens.

Achmetes? In that name I heare an ease

Of all my griefes pronounced, he shall suffice

To banish vsurpation from my throne,

Did furyes guard it round, hee's able well

To reach my Kingdomes from the gripes of hell. (II,ii, 145-152)

The Ottoman Sultan Bajazet is historically known to have an absolute power which makes him tyrannical. Such tyrannical 'picturesque' portrayal of the actions of Sultan Bajazet was relatively common in Elizabethan chronicle. In this chronicle, the inhumanity of Bajazet was highlighted above all else, and the stereotyped Turk, villainous, savage and bloodthirsty, flying down upon innocent European nations, and slaughtering them extensively, was firmly established in the chronological traditions of the West. It is a "frivolous and useless discourse" of the "pomp and magnificence" of the sultan's court. Though he acknowledges that the "Turks" annals" do not charge Bayazid with fratricide (Knolles 1603, p.201), Knolles elsewhere asserts that "Bajazet . . . first of all the Turkish monarchs imbrued his hands with his brother's blood" (Knolles1603, p.179). The sultan is a formidable, cruel tyrant and brutal murderer. Linda McJannet remarks that English historians made "all the Turks are reduced to devilish automatons, who murder and pillage without any evidence of recognizable human feeling" (McJannet 2006, p.58). Rana Kabbani considers the overall features of Elizabethan dramas and points out that: 
The Saracen, the Turk, ... were key villains in the drama of the period, crudely depicted as such by the lesser playwrights, but drawn with more subtle gradations by a Marlowe or a Shakespeare. Although Shakespeare 'whitewashes' Othello by making him a servant of the Venetian state, a soldier fighting for a Christian power, and most importantly, a killer of Turks (Kabbani 1986, p.20).

Linda McJannetremarks that "although the historians do not hesitate to brand the sultans' words and deeds as cruel, tyrannical, and barbarous, more often than one might expect, they also quote them in moments of moral reflection or magnanimous action" (McJannet 2006, p.47). Moreover, the antagonistic writers chosen from Ottoman bizarre history are also depicted as brutal and repulsive, while man-slaughtering is revealed as a setting for brutality and execution. Sultan Bajazet is proud and cruel. He gives thanks to such fortune for delivering such a great enemy into his hands. Through use of implied analogy, Selimus's triumph over his father BajazethII and his brothers is seen in the Western eyes as a manifestation of provincial justice. This relates his character and their conflict to a conventional archetype in the Christian myth. Goffe's playsets up Turkish stereotypes to produce an evil despot indecisive assessment of the relationships between the Turks and Christians. Ahmed Alam El-Deen states that the stories regarding Turks, frequently with some negative associations of as cruelty, treachery, wickedness and violence, not only overwhelmed and fascinated to the English public, but also enthused English dramatists to present Turkish characters in their plays: 'To satisfy the popular demand, playwrights - like Marlowe, Kyd, Shakespeare, Heywood, Messinger, Peele and Goffe resorted to Turkish history as a source of material' (ElDeen 1984, pp.55-6). He also records that 'playwrights portrayed the Turks as ruthless, brutal villains, and this portrayal drew large audiences to the theatres. The gruesome and malicious Turkish character became extremely popular on the English stage' (El-Deen 1984, p.56).

\section{THE SUCCESSION LAW OF FRATRICIDE}

The Ottoman succession stories are a potent source of fascination. The theme of royal succession is not a mere coincidence that the dramatists' accounts of civil wars, kin slaying and fratricide executed in certain Ottoman periods revealed the confusion in the English magistrate's court and the regal family throughout the early Tudor and Stuart bloody conflicts. The English spectators were acquainted with the archetypal tragedies of fratricide predominantly at times when the future of England's throne was at risk. As a result the Elizabethandramatists were similarly interested in the Ottoman emperors who would execute their brothers one or the other at the point of holding control of the kingdom or through the military conflicts that broke out to decide on anheir to the empire. For instance, Elizabethan audiences were conscious that Bajazet slaughtered his brother Jucub while he anticipated authority and that Mehmed II, subsequently assembling somebody to murder his own brothers, arranged fratricide into law in an attempt to bound the civil wars that exploded after a sultan's death (Knolles 1603, pp.337-8). The extension of Bajazet's reign is underscored in the context of Ottoman royal policy of succession and selection. The struggle between royal structures established on congenitalhonors and heirloom as contrasting to the notion of individual value and reliability in communal office turn out to be the motivation of the tragedy. This is proposed by the prominencethat the Ottomandignityemployedin their 'country's good' (Selimus,X, 945-947), when fulfilling their commitments in Robert Greene's Selimus. Matar put up with that the promotion of negative stereotypes of Muslims in English Renaissance writings transpired mainly within dramatic and religious writing, while other types of texts demonstrated to the understanding, certainly sharing between Europeans and Muslims. Matar criticizes the extreme critical reliance on dramatic material to account for English visions of Islam because: from Kyd to Mason and Goffe, Muslims were portrayed on stage without any uniquely differentiating features; they exhibited the moral, or more frequently the immoral, character of Shakespeare's "superstitious Moor" and Goffe's "raging Turke," but there was no allusion in either the characterization or the dialogue in drama to specific aspects of Muslims that could be traced to actual meetings with them (Matar 1999, pp. 6-7).

In Goffe's Amurath, Amurath's son Bajazet bids to share the empire with his brother Jacup, but Schahin and others retell him that 'the Turkish Lawes' need Jacup's death (V,iv,143). Jacup scolds Bajazet and tolerates himself to be choked, enfolding his own scarf about his neck and proposing the other end to Bajazet. Subsequently Lala Schahin's association, he appeals Jacup, his younger brother and is choked to death. The conclusion of the play's verse argument shows Bajazet's fratricide as distinguishing of politics, not of Turks: 'Thus still springs / The Tragick sport which Fortune makes with Kings' (Amurath, Argument, 23-4). Goffe does not discuss individually to the Ottoman Sultan Murad I (1362-89), only the third of the Ottoman family, who has established the precedent for fratricide when he murdered his brothers after he came to power (Imber 2002, pp.97-8). Goffe utilizes the theme of kinsmen killing in the second play Bajazet. Ottoman historical conspiracies also are enforced by the extinguishing of family members' lives within the 
Ottoman royal household in order to achieve imperial power. As Burton has argued, Ottoman historical conspiracies rearrange England's issues into the context of the Ottoman royal family, resulting in a sympathetic depiction of the Ottomans (Burton2005, pp.180-95). Joy Pasini says that the succession to the Ottoman sultanate drove much differently than the succession to the English kingdom, and this gave rise to the dramatic exemplification of the Ottoman sultan as kin killer (Pasini 2001, p.3). Halil lnalcik describes that "there was no law or custom regulating succession to throne. As said by old Turkish beliefs, the appointment of the sovereign was in the hands of God and, therefore, to establish a fixed law of succession or actively to challenge the enthroned sultan was to oppose the will of God"(Inalcik1973, p.59). Pasini remarks that the matters of kindness and justice are used in the Islamic dramas to exam borders neighboring nations, religions, races, and cultures: the dramas observe how kindness and justice operate within the borders of other nations and empires, and how they operate to challenge borders or tighten them (Pasini 2001, p.182).Some of these plays feature the Islamic rulers' killing or potential killing of family members and lovers.

The fascinating part about the Law of Fratricide was that it contributed to all future Ottoman sultans consent to kill their brothers upon assuming rule.In affirming the law, the historical Sultan Mehmed II endorsed the killing of his own sons by one another because he gave permission for one of his sons who came to power to put all of his brothers to death. The Ottoman historian John Kautsky quotes the Law of Fratricide: "whoever among my illustrious children and grandchildren may come to the throne, should, for securing the peace of the world, order his brothers to be executed. Let them hereafter act accordingly" (Kautsky 1997, p.243). Kautsky similarly argues how the Law of Fratricide in practice involved killing any man who could probably intimidate the sultan's power or the power of his supposed heir. It was not just brothers who were killed, but all loyal to them (Kautsky 1997, p.243). During the same time while both countries were encountered with issues such as the succession to the throne, popery and factionalism, authors even criticized the Stuarts and the Catholic monarchs of Europe in a spirit of appraisal with the Ottoman Empire. For instance in his Political Reflections on theGovernment of the Turk (1656) Francis Osborne writes admirably about the Ottoman regime:

[The Ottoman practice is of subjecting ecclesiastical power to civil power. The Ottoman state was no more brutal and tyrannical than the monarchies of Europe. With the Ottomans power depends upon merit rather than birth; hence the Ottomans are free from corruption and idleness, the ruination of Christianity (Osborne 1656, pp.289-95)
The law of fratricide was supportive in holding the Ottoman government together in the course of the fourteenth and fifteenth centuries, but shortly began to be counterproductive. Imperial sons recognized that the death of their father would be a life or death state for them, so they worked hard to gain supporters and accumulate an army to cope with this occasion. Military and financial support were made potential for the reason that a sultan's sons were, at this stage, sent to administrate provinces in Asia Minor, and their capability there not only prepared them for the sultanate but also made them intolerant for a chance at the throne (Parry 1976, p.133). The best egregious example of the law of fratricide happened during the reign of Mehmed III (1595-1603) who slayed his nineteen brothers after ascending to the throne. His period in office also manifest the truly end of the law of fratricide because he had only two sons, making fratricide a threat to the constant existence of the line descended from the first sultan Osman (Parry 1976, p.134). In place of fratricide, brothers were confined within the palace in what was called the cage (Inalcik 1973, p.60). The succession approved from one brother to the next and proceeded to the next generation when no more brothers were left. In the meantime, the practice of nominating the sultan's brothers (and sons) to govern provinces was concluded, in consort with the law of fratricide, the brothers were no longer as well prepared to rule the empire when it was their turn to be sultan (Parry 1976, p.135).

The Ottoman government is an absolutist authority, under the rule of the Sultan, but ironically affected by ambiguity due to a headship that is in a perpetual state of instability hinging on the armedcapacity and popularity of the mandate. Knolles' interpretationafforded the plain framework for this drama that was overstated by the playwright with an amazing amount of mayhem. In relation to Knolles, Bajazet was clever to reestablish reconciliation in his realm by an efficient elimination of those entire participants in the disruption notwithstanding of their association to him (Knolles 1603, pp. 444-45). In Goffe's show, some of the complication of this radical scheme is connected by the roles acted by the three Bassaes: Isaack, Mesithes and Mustapha. They denote a scheme in which ideology instead ofinheritance regulates authority. Meanwhile the aspiration for the throne involves the brutal removal of all opponents. As said by BassaIsaack, the pursuit of theimperialpower needs good planning and apromising success. Isaacksays: An Empire be our hopes; that to obtaine/ Wee'le watch, plot, fight, sweat, and be colde againe' (III,iii,104-5).

Farhana Khan finds that the clan of the Sultan, his Bassas and his warriorsengaged in a fundamental role in the succession (Khan 2011, p.144). On the other hand,Goffe 
has abridged the strategicfeature of the several assassinations to live ultimatelyin the assumed insanity of the King. The incompatible Ottoman Sultan is detested and fearful. The tragedy residesin the essential dimness in a regime where the succession is unjustified and at the mercy of the capability of the successors to survive internecine disputes and court conspiracies. The Sultan's arrogant tone says that a stream of blood haspurgedhimin black suspicionto kill his valiant sons (III,i,230-2). The play encircles in the killing of the royal family to secure the kingship to Bajazet. Vitkus remarks that "the Great Turk became a European bogey partly on the strength of a dynastic track record of executions, poisonings, strangulations, and general familicide' (Vitkus, 2000, p.18). Bajazet does not disagree with his unkind deeds, but he is given the opportunity to rationalize them. Bajazet decides to rule without fear and distrust of his kindred.The Ottoman sultan had put the Ottoman Empire in danger. Bajazet is willing to killeveryone who does not line his martial missions as showed by his horrid absurdity(III,i,68-72).

The Ottoman hierarchy is depicted as exercising its right to maintain power at all cost.The Ottomans pursued a consistent policy, and possessed the military strength and centralized authority necessary for its execution (Inalcik 1994, p.7). Vitkus notes that the 'English representation of the Ottoman royal house as a dysfunctional family that is power hungry and unnaturally murderous' (Vitkus 2003, p.121).Despite the fact that the scenes of barbarism in the East were maintained through this play, the significance was on the polemical presentation of the Ottoman traditional state power against fundamental policies of authority. An effort was made to justify the unusual successes of the Orientalkings in spite of their apparent part as infidel despots of Christendom. On the other hand, playwrights were watchful to display a disdain of recognized religious establishments amongst the challenging parties in the Ottoman Domain which were purposely represented as being without the spiritual constrictions of the customary European empires. Therefore, in place of a Satan or an anti-Christ, the Ottoman sultan was described as a materialistic prince in the early modern perspective, while this attitude denied the antique image of the Turk as the defender of Islam (Khan 2011, p.155). In this approach, the English playwrights utilize their own descriptions of Turkish personalities to explain the extraordinary triumphs of the Ottomans. Hence, the dramatists in England could pointthe Ottoman triumphs to the principles and integrities that reserved the Europeans from being ruthless even with their family successors.

\section{THE RAGE OF BAJAZET}

'The epithet 'ragingTurk ' exemplifies the consequences of the anger of the Ottoman Sultan which claims the lives of many people including his own sons. Goffe's raging Bajazetis the milestone play which asserts on the stereotype of the furious Turk and personified the spirit of the Turks' own chronicles. By dramatizing Bajazet's tragedy for his audience, Goffe reinvents the Ottoman Bajazet II in the appearance of a Machiavellian and opportunist politician whose proclamations are obsolete and inconsistent in an Ottoman prince of the sixteenth century. From a lordly position, the arrogant Ottoman sultan sits on the throne and hecan see the entire world. The enigmatic Sultan is an arrogant infidel monarch who asserted on his magnitude.His presence is amazing by his entourage with their exquisite clothes and appearance. His figure is a static type, inaccurately demonstrating the 'pagan' as such, or the indication of anti-Christian powers, was not simply classified to allegorical usages as in Mummers' Plays (Akalin 2001, p.4).Goffe had quickly realised the potential of dramatizing Ottoman history. His play demonstrates how the history of the Ottoman dynasty can naturally adapt to a classical tragic model cantered on a noble house and provide a rich source to illustrate the favourite Senecan themes of change of fortune, revenge and tyranny.Goffe exposes his view of Bajazet as a brutal unpredictable tyrant. It indicates the fictional images conventionally associated to the Ottomans, the common foe of Christians, such as their 'evilness', 'treachery' and 'lust', etc. shared with material and accounts introduced by Richard Knolles (Senlen 2005, pp. 379-393). Eventually Bajazet draws an offensive but outspoken assumption and admits the name of "tyrant." In Goffe's Amurath, Bajazet has killed his brother Jacupwhich is a portrait of himself as a fratricide and a tyrant during the early years of his reign. In Bajazet Goffe is arresting an appropriate punishment on terrific and unsocial wrongdoers including Bajazet.

Dynastic ambition is the ruling passion of Bajazet II to assume the lives of his seven sons. He longs for power and glory, as Emperor of Turkey. He has turned his latent ambitions to the Ottoman throne into flame. He has been worried over the changes raised by the popularity of his sons.

Baia.Am I not Emperor? hee that breaths a no,

Damnes in that negative fillable his soule,

Durst any god gain-say it, he should feele

The strength of fiercest Gyants in mine armes,

Mine angers at the highest, and I could shake

The firme foundation of the earthly Globe:

Could I but graspe the Poles in these two handes,

I'de plucke the world asunder; droppe thou bright Sunne,

From thy transparant Spheare, thy course is done,

Great Baiazet is wrong'd not shall thine eye 
Be witnesse to my hatefull misery.

Madnesse and anger makes my tongue betray,

The Chaos of my thoughts: vnder this brest,

An heape of indigested cases are prest.(I,i,52-65)

His youngest son, the wise and gentle Corcutus, contests his father for power but concedes to his father to avoid civil war. Although for a short time interested in power, the unconscious ambitions of the crown court finally disgust him, and he decides to devote his lifetime to retired scholarship. At the same time, Bajazet realizes the ambition his younger brother, Zemes has for power.

Bish.Imperious Turke,

Am I not Gods Vize-gerent here on earth,

And dar'st thou send thy letters of command?

Or speake to me in threatning menaces?

It grates my patience to obey this monster,

Yet must I murder Zemes, what doe I know

Whether my fathers soule did trans-migrate

Into his breast or no? be dumbe remorse,

The Turke is great and powerfull, if I winne

His loue by this, t'will proue a happy sinne. (II, viii, 45-

54)

Sultan Bajazet II realises that there is a smoke of treason and hesparkshisburning sword for revenge. Bajazet learns of his brother Zemes's journey to Armenia to get a support by its King against Bajazet, and decides to destroy this threatin the battlefield with the help of Achmetes. Before meeting Zemes' forces, Bajazet instructs his sons Trizham and Mahomet to stop Zemes from fleeing after the battle to Rome but they could not do so.The Pope of Rome has gallantly received the fugitive Zemes, but he rejects to aid him against Bajazet. When Bajazet asks the Pope to murder Zemes, however, he agrees in order to avoid confrontation with Bajazet, and slayed his innocent guest with poison.

Baia.I'de rattle such new torments in their eares,

Should stagger their high courage; but my feares

Strangle my furies, and my enuious fate

Forceth my tongue to flatter, where I hate.(II, vi, 223-6)

In a conspiracy, Isaack plots an infidelity against his sonin-law Achmetes because of his divorcing Isaack's daughter. When the revengeful Isaack conveys to Sultan Bajazet II that Achmetes has significantly permitted Zemes to flee, the fuming father, Bajazet, pledges to penalise his sons for the treason.On Bassa Isaack counsellingthe furious Bajazet themandateof the general Death's Mantle, the emperor approves murderingany person including his sons. In doing so, Sultan Bajazet invited his family members for a victory celebration. At the end of the party, he ordered the guards to execute all. There was a chaos among the attendance as princes were slaughtered. On the other hand, some janissaries
liberatedCaigubus, the son of Achmetes, andthreatened the emperor with death instead.

In a treacherous move, theupset Bajazet plans to pardon Achmetes, and declares a war against Rome. Mahomet and Trizham attempt to convince him to preserve the reconciliation with Rome, but the bloody wrathful Bajazet commands the death of his own sons, and individually strangles them with the assistance of Isaack, Selymus, and Mesithes for their failure to stop Zemes' flee. At that moment he stabs his son Achmetes to death. In his rage, the tyrant Bajazet feels himself uncontrolled, and threatens to murder himself, but is prevented by the courtiers; yet he feels cursed by what he has done. The wild Bajazet offers the region of Amasia to his son Mahomates (yet he is made envious by the people's love for this prince), but says to Selymus he is still too young to rule. Mahomates recruits the nameless mute Monk to assassinate his father; but the attempt fails. This makes him realize that authority has not brought him happiness but apprehension; and therefore, he decides to crown the ambitious Achometes in his positon and withdraw to a quiet retirement. When he has Achometes proclaimed the king, conversely, the public rejects him. To satisfy his panic of his son Mahomates, the angry Bajazet persuades his son's supposed friend, Asmehemedes, to slaughter Mahomates, and then he murders the hired murderer in response.

The violent Bajazet becomes a flame of fire in an irritating heat which distempers all his blood. Goffe describes Bajazet'svengeancemaking an earthquake in the great City of proud Constantine, Constantinople. At his fierce anger, he turns to destroy his foes including his family members. Returning to Constantinople, Bajazet is trapped by Selymus and his Tartarian groups, but he successfully leads the insurgents from the battlefield. On the other hand, Achometes kills the mute ambassador of his father. When his body is presented to the emperor Bajazet and the court, it makes Bajazet very upset and he chooses Selymus, not Achometes, as his successor. Goffe describes the hopes of ambitious princes asbeing wrapped in the fatal cloud of death.

The raging Bajazet gets to know that Achomates has revolted on knowing that the people choose his father, and he resolves on the instruction of the Bassas to assign Selymus as his successor andAchomates outrageously felt disgraced furious. Under Haman's attention, the frantic emperor Bajazet II reflects on the moods of political fortune, and he visualizes that he will by some means rise above humanity he passes away. At a midnight engagement, the conspirators,Achomates, Selymus, Isaack, Cherseogles, the Bassas,and Mustapha fall all victims of their ambitions and darkness. They have killed the two emperor's brothers and each other.They are the 
victims of Bajazet's ambition, as he is led up to his death by poison and Syloman becomes the emperor.

The depth of these villainies is the soul of the monster, Bajazet. The proud Bajazet has taken his furious feelingsto sacrifice his sons at the shrine of his displeasure. He winks at these notorious crimes. When Corcutus gives up the throne to Bajazet, Selymus moves his antagonism to his father, and assumes a Machiavellian conspiracy to gain power for himself. At Isaack's plan, he gains the support of Mesithes, Mustapha, and Asmehemides by providing them gifts. Even though he aids Bajazet, he slaughters his sons Mahomet, Trizham, and Achmetes.He is more infuriated when his father declines to give him a region to rule because he is too young. He decides to escape from the court, but to come back to take over his father. Shortly with the support of the Tartarian King, he triumphs over Thrace. The father Bajazet reprimands his captain Cherseogles over Thrace, but Cherseogles secretly sets an ambush for the Bajazet outside Constantinople. In the battleground, the two sides come face to face, but Bajazet places Selymus and his Tartarian followers in confusion. Hardly, Selymus restores his army, but he learns of Bajazet's wish indefying his brother, Achometes. Selymus again pretends obedience, and leavesthe battleground but he virtually at once proceeds with his encouraging troops, demanding his father Bajazet to resign.

The Emperor Bajazet presently moves to confront Achometeswho is enticed by Cherseogles in disguise to a middle of the night engagement, where the Turkish Bassas slay him. At the end of the play, Prince Solyman triumphs and becomes the new Emperor. Historically, Solyman was one of the most magnificent of Turkish Sultans whose rulemanifest the peak of the Ottoman Kingdom. He is the virtuous leading figure who revives the assignment of his Ottoman prototypes in his determination to drive forward the borders of the Kingdom(V, x, 108-114).However, the dreadful reappearance of slayings and killings in the Ottoman family are publicized to remind a world in which bloodletting is supposed as constructiverevenue of maintaining the welfare of a Kingdom; he states that "we shall thinke goode,\#With warre to let the body politick blood"(V, x, 183-90). The horrific atrocities of the Turkish imperialismlay onseveral disasters on Europe and Christians. In the European continent, Christian religious groups and Europe governments had effectively prevented therealization of a united Europe under a single religion and a crusade against theOttoman Empire(Akalin 2001, p.143).

Goffe finds out in the narrative of countless murders, poisonings and suicides a message to England that killing is legitimized when it terminates, rather illogically, in the advent of the best contender for the crown. Goffe's works about the Turks exploited the common perception of the Jacobean community for manslaughter and chaos on stage, but there is similarly a stout commendation of the martial attitude to Empire construction, best showed by the Ottomans, which pursues to overwhelm any Christian fears. While the techniques assumed by the Turks in the play are evidently passionate, their conquests challenge upright criticism. Since the Elizabethan and Jacobean governments' scheme of answering back to any dangers to the kingship, the Ottomans do not do something that could have astonished the spectators of these dramas, used to the public violence of the Tudor systems in the past. The Ottoman pyramid is portrayed as working out its right to preserve power at all cost.

\section{CONCLUSION}

The play shows the historical role of the feared villainous sultan on London stage.The play presents a fascinating image of the Turk as a symbol of the decontrol over the other in history playwriting. Elizabethan dramatists addressed the image of the top dynastic Turks as violent ancestors. The Ottoman rulers offer fascinating and problematic material for early Elizabethan authors. The account of the clan's murders provided a sensational plot for in Early Modern English drama. The Turkbeing fearful andfascinating, tyrannical and evil, warand conquests, fratricide, dynastic loyalties and disloyalties, rebellions, pride and humiliation, alien yet familiar allows Elizabethan authors to identify these themes to the audience.

The play's principal preoccupations, the embedding of the sultan's power within the boiling palace system, the bogus theocratic claims on which it was based, the instability of a succession that restored on intra-familial murder, and the tyrant ruler to ruthless and ambitious brothers within his own household, are all characteristic of contemporaneous Western histories of the Turks. Therefore,Elizabethan depictions contextualized and examined the practices of demonstrating the Ottoman on theatre as the West's Other. During the course of history, cultural encounters between the East and the West have established a conflict between WesternSelf and the Ottoman Other.Goffe's Bajazet the Secondexplores the barbarism of the exotic Ottoman Other.Goffe's play presents the fantasy of the subjugated or condemned the Ottoman sultan that is so common in Elizabethan drama to establish Otherness. Goffe's Bajazet exposes a broad range of socio-political, psychological and moral matters in the Ottoman imperial house. The Elizabethan and Restoration audiences observe a parade of images of all archetypal Ottoman citizens, who are evident through theirethnic and regional attributes. 
Goffe's Bajazet is depicted as a violent blast of angry Bajazet whose wrath spoils the lives of many people. His cruel homicide sends his foes to hell.It incenses the angry Emperor whose bosom is as black as night. His blood boils in his breast with anger. Following the treasons of his sons which were at race running with high speed though they are in peace, he appears as a devoted and wicked heathen.Goffe's portrayal of Bajazet II as a stranger of the Christians has no comparison in the historical sources. This ahistorical representation of Bajazet would mark it challenging for English spectators not to feel involved in the struggle and identify with Bajazet, who has the prosperity of Christians at heart. At the same time, the emphasis on Bajazet's favourable approach towards Christianshighlights the image of the Sultan as a devoted enemy to Christianity. Though, the Ottoman Empire stirred into a stable economic and political relationship with England (Burian 1952, p.209), the designations assumed to the Ottoman Emperor in Thomas Goffe's The Raging Turke are also used to propose his hostility to Christendom as a holy warrior. Bajazet II is designated in the play as 'subverter and swone enemie of the Christians, and of all that call upon Christ' (IV,iii, 141-2).At the end of the play, the tragic end of the tyrant brings relief to the audience. Elizabethan audiences would have felt no compassion for the vanquished sultan (Burton 2005, p. 78). Bajazet II looks like a broken and pitiable character. His humiliation and misery are established in the scene of the banquet.

\section{REFERENCES}

[1] Akalin, Esin. (2001). Discovering Self and Other, representations of Ottoman Turks in English Drama. Doctoral Dissertation, University of Toronto.

[2] Bayouli, Tahar. (2008). 'Elizabethan Orientalism and its Contexts: The Representation of the Orient in Early Modern English Drama.' International journal of Euro-Mediterranean studies (2008 Vol I. no.1, 109-128. p.115).

[3] Beck, Brandon.(1987).From the Rising of the Sun: English Images of theOttoman Empire to 1715.New York: Peter Lang.

[4] Belgasem, FatimaEssadek Ali (2013) Representations of Ottoman Sultans in Elizabethan Times, Durham theses, Durham University. Available at Durham E-Theses Online: http://etheses.dur.ac.uk/7384/

[5] Blount, Henry. (2008). A Voyage into the Levant, 4th Edition, 1640. Cited in Anna Suranyi, The Genius of the English Nation: Travel Writing and National Identity in Early Modern England. Cranbury: Associated University Presses.
[6] Bowers, Fredson (1987). (Ed.) 'Thomas Goffe.' Dictionary of Literary Biography, Volume 58: Jacobean and Caroline Dramatists. University of Virginia. Gale.

[7] Burian, Orhan. (1952). "Interest of the English in Turkey as Reflected in English Literature of the Renaissance". Onéns 5 (1952): 209-229. pp.209

[8] Burton, Jonathan. (2005). Traffic and Turning: Islam and English Drama, 1579-1624. Newark, University of Delaware Press.

[9] El-Deen, Ahmed Alam. (1984). A Critical Edition of Thomas Goffe's The Raging Tyrke, or, Baiazet the Second (1631), unpub. diss. West Virginia, West Virginia University.

[10]Esen, M. Fatih \& Karakuzu, Melih. (2011). Misrepresentations of Turks in Early Modern Drama and Motivations Underlying This Denigration. 1st International Conference on Foreign Language Teaching and Applied Linguistics May 5-7, 2011. Sarajevo, p. 867.

[11]Faroqhi, Suraiya. (2004). The Ottoman Empire and the World around It. London, Tauris.

[12] Goffman, Daniel. (2007). 'Negotiating with the Renaissance State: The Ottoman Empire and the New Diplomacy', in Virginia H. Aksan and Daniel Goffman (eds.), The Early Modern Ottomans: Remapping the Empire. Cambridge, Cambridge UP.

[13] Greenblatt, Stephen. (1980). Renaissance SerfFashioningfrom Marlowe to Shakespeare. Chicago, University of Chicago Press.

[14] Imber, Colin (2002). The Ottoman Empire, 13001650: The Structure of Power. Houndmills, Basingstoke, Hampshire: Palgrave Macmillan.

[15]Inalcik, Halil. (1973). The Ottoman Empire, the Classical Age 1300-1600. trans. Norman Itzkowitz and Colin Imber, London, Weidenfeld and Nicolson.

[16] Inalcik, Halil. (1994). ed. An Economic and Social History of the Ottoman Empire (13001914).Cambridge, Cambridge University Press.

[17]Kabbani, Rana. (1986). Europe's Myths of the Orient. London, Macmillan.

[18] Kautsky, John. (1997). The Politics of Aristocratic Empires. New Brunswick: Transaction Publishers.

[19] Khan, Farhana Wazir (2011). 'Mirrors of Governance: 'The Mighty Turkish Diadem and English Drama (Selimus. Sc.xxvi.2340)' Journal of European StudiesVols. 26 \& 27, Nos. 2 \& 1 July 2010 \& January 2011, pp.139-169.

[20] Knolles, Richard. (1638) Historie of the Turkes. London, printed by Adam Islip, 1603; reprinted.

[21] Kugler, Emily. (2012). Sway of the Ottoman Empire on English Identity in the Long Eighteenth Century. Leiden, Brill. 
[22] MacLean , G. ( 2007 ). Looking East: English Writing and the Ottoman Empire before 1800 , Basingstoke : Palgrave Macmillan .

[23] Matar, Nabil. (1999). Turks, Moors, and Englishmen in the Age of Discovery. New York, Columbia UP.

[24] McJannet, L. (2006). The Sultan Speaks: Dialogue in English Plays and Histories about Ottoman Turks Basingstoke : Palgrave Macmillan

[25] Minchinton, W.E. (1969). The Growth of Overseas Trade in the Seventeenth and Eighteenth Centuries. London: Methuen.

[26] Osborne, Francis. (1656).Political Reflections Upon the Gouernment of the Turks. London.

[27] Pasini, Joy. (2011). "Kin with Kin and Kind with Kind Confound": Pity, Justice, and Family Killing in Early Modern Dramas Depicting Islam. Unpublished $\mathrm{PhD}$. Thesis. Rice University, Houston, Texas.

[28] Parry, V.J. (1976)."The Period of Murad N, 161748," in A History of the Ottoman Empire to 1730, Chapters from the Cambridge History of/slam and the New Cambridge Modern History, ed. M.A. Cook (Cambridge: Cambridge University Press.

[29] Purchas, Samuel. (1905). Hakluytus Postuhumus or Purchas His Pilgrimes, 20 vols Glasgow; James MacLehose and Sons, VIII, pp.304-320.

[30] Rice, Warner Grenelle (1926). Turk, Moor and Persian in English Literature from 1550-1660, with particular Reference to Drama. unpublished doctoral thesis, Harvard University.

[31] Schmuck, S. ( 2005 ). "The "Turk" as Antichrist in John Foxe'sActs and Monuments'. Reformation'. 10, $21-44$.

[32] Schwoebel, Robert. (1967). The Shadow of the Crescent: The Renaissance Image of the Turk. Nieuwkoop: B. De Graaf, pp. 176-201.

[33] Senlen, S1la. (2005). "Richard Knolles' The Generall Historie of the Turkes as a Reflection of Christian Historiography", OTAM 18 (2005). pp.379-393.

[34] Sisneros, Katie S., "Fearing the "Turban'd Turk": Socio-Economic Access to Genre and the "Turks" of Early Modern English Dramas and Broadside Ballads" (2010). Dissertations \& Theses, Department of English. Paper 20. http://digitalcommons.unl.edu/englishdiss/20

[35] Slotkin, Joel Elliot (2009). "Now will I be a Turke': Performing Ottoman Identity in Thomas Goffe's The Courageous Turk', Early Theatre 12.2 (2009): pp.222-35.

[36] Vitkus, D. (2000). Three Turk Plays from Early Modern England. New York : Columbia University Press .
[37] Vitkus, D. (2003). Turning Turk: English Theater and the Multicultural Mediterranean, 1570 - 1630. Basingstoke, Palgrave Macmillan. 